\title{
PENGARUH NON PERFORMING FINANCING, KECUKUPAN LIKUIDITAS, KECUKUPAN MODAL DAN INFLASI TERHADAP BIAYA OPERASIONAL TERHADAP PENDAPATAN OPERASIONAL (BOPO) PADA BANK UMUM SYARIAH PERIODE 2011-2017
}

\author{
Yulius Dharma ${ }^{1}$ \\ Rani Puspitaningrum, SP., M.SEI ${ }^{2}$ \\ Dhaifa Usriya ${ }^{3}$ \\ yulius.dharma@unimal.ac.id \\ 2rani.puspita@unimal.ac.id \\ 32dhaifa.160440066@mhs.unimal.ac.id
}

${ }^{1}$ Islamic Economics Department, Faculty of Economics and Business, University of Malikussaleh

${ }^{2}$ Islamic Economics Department, Faculty of Economics and Business, University of Malikussaleh

${ }^{3}$ Islamic Economics Department, Faculty of Economics and Business, University of Malikussaleh

\section{ARTICLE HISTORY}

Received:

11 April 2021

Revised

13 April 2021

Accepted:

27 May 2021

Online available:

19 Juni 2021

Keywords :

Non Performing

Financing (NPF),

Financing to Deposit

Ratio (FDR), Capital

Adequacy Ratio (CAR),

Inflation, Operational

Costs to Operating

Income (BOPO),

Autoregressive

Distributed

Lag

(ARDL).

*Correspondence:

Name:

Dhaifa Usriya

E-mail:

dhaifa.160440066@m

hs.unimal.ac.id

\section{ABSTRACT}

This study aims to analyze the effect of Non Performing Financing, Financing to Deposit Ratio, Capital Adequacy Ratio and Inflation on Operational Costs to Operating Income (BOPO) in Islamic Commercial Banks period 2011-2017. The data used in this research is secondary data with a quantitative approach in the form of monthly time series from 2011 to 2017. The method of analysis used in this study is to use the Autoregressive Distributed Lag (ARDL) model with data processing using Eviews 9 software. The results of this study shows that in the long term and short term NPF has a positive and significant effect on BOPO. In the long term and short term FDR has a negative and significant effect on BOPO. In the long term CAR has a negative and significant effect on BOPO while in the short term CAR has a positive and significant effect on BOPO. In the long term and short term inflation has a positive effect on BOPO but in the short term inflation also has a significant negative effect on BOPO. Based on the results of the research it can be concluded that the NPF, FDR, and inflation show a consistent effect, this means that there is a correction from the long term to the short term. Meanwhile CAR has an inconsistent effect.

Keywords : Non Performing Financing (NPF), Financing to Deposit Ratio (FDR), Capital Adequacy Ratio (CAR), Inflation, Operational Costs to Operating Income (BOPO), Autoregressive Distributed Lag (ARDL). 


\section{PENDAHULUAN}

Kegiatan pembangunan perekonomian tidak dapat dilepaskan dari sektor keuangan di karenakan sektor keuangan sudah menjadi instrumen yang penting dalam pencapaian perekonomian khususnya sektor perbankan. Di indonesia saat ini terdapat dua jenis perbankan atau dapat disebut juga perbankan ganda (dual banking system) yaitu perbankan konvensional dan perbankan syariah yang mulai di atur dalam undang-undang No. 7 Tahun 1992.

Sebagai lembaga keuangan yang penting dalam pembangunan perekonomian indonesia perkembangan perbankan syariah tentunya menjadi hal yang diperhatikan. Perkembangan perbankan syariah harus diiringi dengan perkembangan peningkatan kinerja yang efektif dan efisien sehingga akan berdampak pada peningkatan kepercayaan nasabah dalam menggunakan jasa layanan perbankan syariah. Rasio yang mencerminkan tingkat efisiensi kinerja bank syariah ditunjukkan oleh rasio Biaya Operasional terhadap Pendapatan Operasional (BOPO). Apabila rasio BOPO semakin tinggi menandakan bahwa efisiensi dalam pengelolaan bank syariah rendah namun apabila rasio BOPO semakin menurun maka semakin baik kinerja bank syariah, sehingga rasio BOPO harus diperhatikan untuk mengetahui semakin tinggi atau semakin turun rasio BOPO setiap tahunnya.

\section{PENELITIAN TERDAHULU}

Shinta Puspitasari Hidayat dan Ari Prasetyo (2016) "Pengaruh Non Performing Financing, Financing to Deposit Ratio dan Inflasi Terhadap Efisiensi Menggunakan Rasio Bopo pada Bank Syariah di indonesia Periode 2010-2015". Penelitian ini menggunakan teknik regresi linier berganda dengan sumber data dalam penelitian adalah data sekunder yang dikumpulkan dari sumber yang relevan.

Taudlikhul Afkar (2017) "Analisis Pengaruh Kredit Macet Dan Kecukupan Likuiditas Terhadap Efisiensi Biaya Operasional Bank Umum Syariah Di Indonesia". Penelitian ini mencakup seluruh Bank Umum Syariah di Indonesia periode 2012-2014 dengan teknik Regresi Linear Berganda.

Ravika Fauziah (2012) "Analisis Pengaruh Inflasi Terhadap Tingkat Profitabilitas Bank Muamalat Indonesia dan Bank Centarl Asia (BCA) Tahun 2007-2011". Metode yang digunakan ialah metode kuantitatif dengan teknik Analisa Regresi Linear.

\section{DESAIN PENELITIAN}

Penelitian ini menggunakan metode kuantitatif berbentuk time series dimana semua variabel yakni Non Performing Financing (NPF), Financing to Deposit Ratio (FDR), Capital Adequacy (CAR), Inflasi dan Beban Operasional terhadap Pendapatan Operasional (BOPO) memakai data bulanan dari tahun 2011 sampai 2017. Data yang digunakan dalam penelitian ini berasal dari laporan keuangan Bank Umum Syariah (BUS) bulanan periode 2011 sampai 2017 yang diperoleh dari situs resmi Otoritas Jasa Keuangan dan Bank 
Indonesia. Adapun metode yang digunakan dalam penelitian ini menggunakan metode dokumentasi.

\section{HIPOTESIS PENELITIAN}

Ho : Non Performing Financing (NPF), Financing to deposit ratio (FDR), Capital Adequacy Ratio (CAR) dan Inflasi tidak berpengaruh terhadap Biaya Operasional terhadap Pendapatan Operasional (BOPO).

$\mathrm{Ha}$ : Non Performing Financing (NPF), Financing to deposit ratio (FDR) Capital Adequacy Ratio (CAR) dan Inflasi berpengaruh terhadap Biaya Operasional terhadap Pendapatan Operasional (BOPO).

\section{METODOLOGI PENELITIAN}

Dalam penelitian ini, penulis menggunakan model Autoregressive Distributed Lag (ARDL) dengan pengolahan data menggunakan Software Eviews 9. Model Autoregressive Distributed Lag (ARDL) yang digunakan meliputi Uji Stasioneritas, Uji Lag Optimum, Uji Kointegrasi, Estimasi Autoregressive Distributed Lag (ARDL), Estimasi Koefisien Jangka Panjang, Estimasi Koefisien Jangka Pendek, Uji Diagnostik dan Uji Stabilitas. Model Autoregressive Distributed Lag (ARDL) dapat di tulis sebagai berikut:

$$
\mathrm{yt}=\alpha \sum_{i=1}^{p} \quad y \mathrm{iyt}-\mathrm{i}+\sum_{j=1}^{k i} \quad \sum_{j=0}^{q j} \quad \chi j, t-i^{\prime} B j, i+E t
$$

Untuk estimasi koefisien jangka panjang dapat dituliskan sebagai berikut :

$$
\ln Y t=\alpha+\beta 1 X 1 t+\beta 2 X 2 t+\ldots+\mu t
$$

Untuk koefisien jangka pendek dapat dituliskan sebagai berikut :

$$
\Delta \operatorname{lnYt}=\alpha+\sum_{i=1}^{p} \quad \theta_{1} i \Delta \operatorname{lnYt}-1+\sum_{j=1}^{q} \quad \varphi_{1} j \Delta \mathrm{Xt}-\mathrm{j}+\ldots+\gamma \mathrm{ECTt}-1+\mathrm{E}_{1}
$$

\section{HASIL DAN PEMBAHASAN}

\section{Uji Stasioneritas Data}

Sebelum mengestimasi variabel menggunakan model Autoregressive Distributed Lag (ARDL), maka terlebih dahulu perlu untuk melakukan uji stasioneritas yang bertujuan untuk mengetahui apakah variabel mengandung akar unit (unit root) atau tidak.

Hasil uji stasioneritas

\begin{tabular}{ccccc}
\hline Variabel & \multicolumn{4}{c}{ Augmented Dickey Fuller (ADF) } \\
\cline { 2 - 5 } & Level & Prob & First Difference & Prob \\
\hline BOPO & -1.114188 & 0.7069 & -15.23794 & 0.0001 \\
\hline NPF & -0.993733 & 0.7521 & -4.570078 & 0.0003 \\
\hline FDR & -0.643625 & 0.8541 & -10.51749 & 0.0001 \\
\hline CAR & -5.298250 & 0.0000 & -11.15916 & 0.0001 \\
\hline INFLASI & -2.409600 & 0.1423 & -6.792323 & 0.0000 \\
\hline
\end{tabular}


Tabel di atas menunjukkan bahwa keempat varibel yakni BOPO, NPF, FDR dan Inflasi tidak stasioner pada tingkat level hal ini ditunjukkan dengan probabilitas yang lebih besar dari tingkat signifikan $\alpha=5 \%$, sedangkan untuk variabel CAR stasioner di tingkat level. Langkah selanjutnya adalah menguji pada tingkat first difference yang menunjukkan nilai probabilita kelima variabel yakni BOPO, NPF, FDR, CAR dan Inflasi lebih kecil dari tingkat signifikan $\alpha=5 \%$ sehingga data tersebut dapat dikatakan stasioner pada tingkat first difference.

\section{Uji Lag Optimum}

Penentuan panjang lag optimum dalam penelitian ini menggunakan kriteria informasi yang diperoleh dari Akaike Information Criteria (AIC) dimana AIC memberikan penalti atas tambahan yang mengurangi derajat kebebasan dan cenderung memilih panjang lag yang maksimal.

Uji Lag Optimum

Akaike Information Criteria (top 20 models)

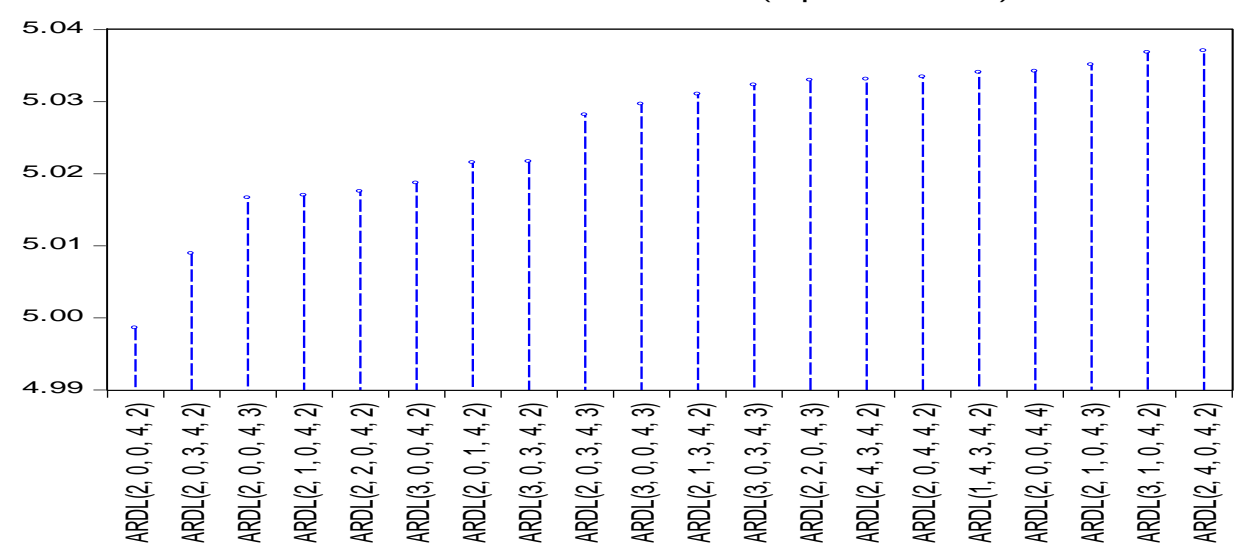

Berdasarkan gambar tersebut dapat dilihat bahwa besarnya lag yang dipilih dalam penelitian ini adalah lag $(2,4,0,4,2)$ dimana $B O P O=2, N P F=4, F D R=0, C A R=4$ serta Inflasi $=2$.

\section{Estimasi Autoregressive Distributed Lag (ARDL)}

Hasil estimasi Autoregressive Distributed Lag (ARDL)

\begin{tabular}{crrrr}
\hline Variable & Coefficient & Std. Error & t-Statistic & Prob. $^{*}$ \\
& & & & \\
\hline BOPO(-1) & 0.076992 & 0.106672 & 0.721757 & 0.4730 \\
BOPO(-2) & 0.216056 & 0.094673 & 2.282122 & 0.0257 \\
NPF & 2.971730 & 0.580895 & 5.115782 & 0.0000 \\
FDR & -0.513793 & 0.105978 & -4.848127 & 0.0000 \\
CAR & -0.512596 & 0.443295 & -1.156331 & 0.2517 \\
CAR(-1) & 0.545761 & 0.498471 & 1.094868 & 0.2775 \\
CAR(-2) & -0.813600 & 0.505038 & -1.610968 & 0.1119 \\
CAR(-3) & -0.707856 & 0.464436 & -1.524121 & 0.1322 \\
CAR(-4) & -0.915127 & 0.351024 & -2.607023 & 0.0112 \\
INFLASI & -0.309807 & 0.572511 & -0.541137 & 0.5902
\end{tabular}




\begin{tabular}{lrlrl}
\multicolumn{1}{c}{ INFLASI(-1) } & -0.836030 & 0.882800 & -0.947021 & 0.3470 \\
\multicolumn{1}{c}{ INFLASI(-2) } & 1.540190 & 0.578428 & 2.662716 & 0.0097 \\
\multicolumn{1}{c}{ C } & 131.6123 & 20.64720 & 6.374341 & 0.0000 \\
& & & & \\
\hline & 0.924966 & Mean dependent var & 85.78713 \\
R-squared & 0.911527 & S.D. dependent var & 9.198620 \\
Adjusted R-squared & 2.736074 & Akaike info criterion & 4.998591 \\
S.E. of regression & 501.5687 & Schwarz criterion & 5.385670 \\
Sum squared resid & -186.9436 & Hannan-Quinn criter. & 5.153782 \\
Log likelihood & 68.82739 & Durbin-Watson stat & 2.027183 \\
F-statistic & 0.000000 & & \\
Prob(F-statistic) & & &
\end{tabular}

Dari hasil pengujian yang telah dilakukan diatas menunjukkan bahwa variabel NPF secara signifikan berdampak positif terhadap BOPO yang dibuktikan dengan nilai koefisien sebesar 2,971730 dan nilai prob. $t$ sebesar 0,0000 yang lebih kecil dari 0,05 . Hal ini menunjukkan bahwa peningkatan NPF pada suatu bulan sebesar $1 \%$ akan meningkatkan BOPO pada bulan tersebut sebesar 2,971730\%. Variabel FDR secara signifikan berdampak negatif terhadap BOPO yang ditunjukkan dengan nilai koefisien sebesar -0,513793 dan nilai prob. t sebesar 0,0000 yang lebih kecil dari 0,05. Hal ini menunjukkan bahwa peningkatan FDR pada suatu bulan sebesar $1 \%$ akan menurunkan BOPO pada bulan tersebut sebesar 0,513793 \%. Variabel CAR tidak berpengaruh signifikan pada bulan pertama (CAR(- 1)), bulan kedua (CAR(-2)) serta bulan ketiga (CAR(-3)) sementara pada bulan keempat (CAR(-4)) berpengaruh positif signifikan dengan prob. $t$ sebesar 0,0112 . Hal ini mengartikan bahwa peningkatan CAR pada 4 bulan sebelumnya sebesar $1 \%$ akan menurunkan BOPO pada bulan sekarang sebesar -0,915127\%. Variabel Inflasi tidak berpengaruh signifikan pada bulan pertama (Inflasi(-1)) dan berpengaruh positif signifikan pada bulan kedua (Inflasi(-2)) yang ditunjukkan dengan nilai prob. t sebesar 0,0097. Dimana menunjukkan bahwa peningkatan BOPO bulan sekarang dipengaruhi oleh peningkatan inflasi pada dua bulan sebelumnya. Apabila ditinjau dari nilai koefisiennya, peningkatan inflasi sebesar $1 \%$ akan meningkatkan BOPO sebesar 1,540190\%. Dengan nilai R-Squared sebesar 0.924966\% menunujukkan bahwa persamaan ini mampu menjelaskan sebesar $92 \%$ atas variabel dependen berdasarkan model yang digunakan dan sisanya merupakan penjelasan dari variabel lain yang tidak masuk dalam model. 


\section{Uji Diagnostik pada Model Persamaan Autoregressive Distributed Lag (ARDL)}

\section{Uji Normalitas}

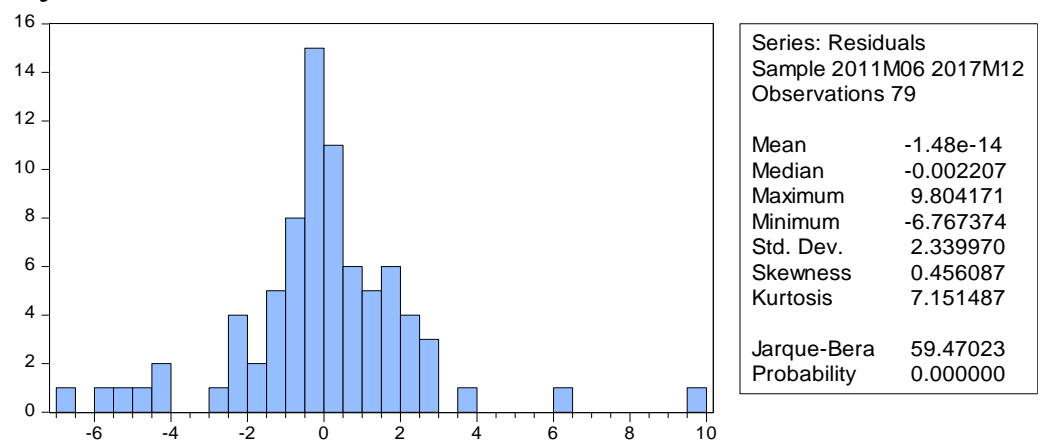

Hasil uji normalitas di atas menunjukkan bahwa data dalam penelitian ini tidak berdistribusi normal, dengan nilai probabilitas 0,000000 lebih kecil dari 0,05. Sehingga peneliti mengasumsikan data tersebut berdasarkan Central Limit Theory (Dielman, 1961 dalam Ghozali, 2009) yang menyatakan bahwa untuk sampel yang besar terutama lebih dari $30(n \geq 30)$, distribusi sampel dianggap normal. Dikarenakan sampel dalam penelitian ini lebih dari 30 ( $n \geq 30$ ) sampel yaitu memakai 84 sampel maka uji normalitas dinyatakan terdistribusi dengan normal.

\section{Uji Autokorelasi}

Breusch-Godfrey Serial Correlation LM Test:

\begin{tabular}{llll}
\hline & & & \\
F-statistic & 1.974281 & Prob. F(2,55) & 0.1486 \\
Obs*R-squared & 5.291672 & Prob. Chi-Square(2) & 0.0709 \\
\hline
\end{tabular}

Berdasarkan tabel dapat dilihat bahwa nilai probability chi square sebesar 0.0709 dimana lebih besar dari nilai signifikan 0,05 sehingga dapat di simpulkan persamaan regresi dalam penelitian ini tidak terjadi autokorelasi.

\section{Uji Heteroskedastisitas}

Heteroskedasticity Test: Breusch-Pagan-Godfrey

\begin{tabular}{llll}
\hline & & & \\
F-statistic & 1.266786 & Prob. F(21,57) & 0.2365 \\
Obs*R-squared & 25.13797 & Prob. Chi-Square(21) & 0.2412 \\
Scaled explained SS & 40.25093 & Prob. Chi-Square(21) & 0.0069 \\
\hline
\end{tabular}

Berdasarkan pada tabel menunjukkan bahwa nilai probability chi square sebesar 0.2412 dimana lebih besar dari nilai tingkat signifikan 0,05 atau 5\%. Dapat disimpulkan bahwa tidak terjadi heteroskedastisitas. 


\section{Uji Stabilitas pada Model Persamaan Autoregressive Distributed Lag (ARDL)}

\section{Uji CUSUM}

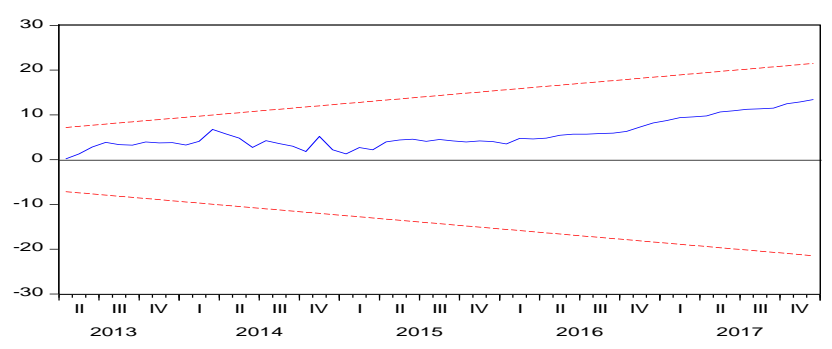

Berdasarkan gambar di atas dapat dilihat uji stabilitas model cumulative sum (CUSUM) dengan taraf signifikansi 5 persen. Model dinyatakan stabil karena garis biru tidak keluar dari batas garis merah. Artinya model ARDL dinyatakan stabil.

\section{Uji CUSUMQ}

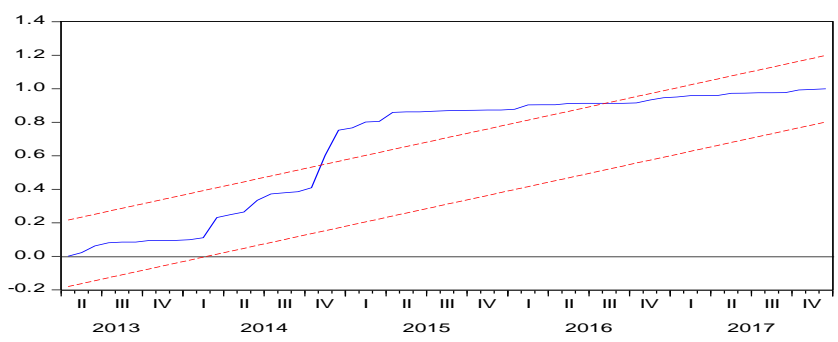

- CUSUM of Squares ---- $5 \%$ Significance

Berdasarkan hasil uji model cumulative sum of squares (CUSUMQ) di atas menunjukkan bahwa garis biru keluar dari batas garis merah dengan taraf signifikansi $5 \%$ sehingga model ARDL dinyatakan cukup stabil dalam CUSUMQ.

\section{Uji Kointegrasi}

Dalam metode ARDL pada penelitian ini, uji kointegrasi yang digunakan yaitu Bound Testing Cointegration dengan menggunakan Wald Test.

\begin{tabular}{ccc}
\hline Test Statistic & Value & $\mathrm{K}$ \\
F-statistic & 8.063779 & 4 \\
\hline & Critical Value Bounds \\
\hline Significance & $I(0)$ Bound & I(I) Bound \\
$90 \%$ & 3,03 & 4,06 \\
$95 \%$ & 3,47 & 4,57 \\
$97,5 \%$ & 3,89 & 5,07 \\
$99 \%$ & 4,40 & 5,72 \\
\hline
\end{tabular}

Hasil Bound Test dengan menggunakan Wald Test di atas menunjukkan bahwa nilai Fstatistic sebesar 8.063779 yang di peroleh pada model ini lebih besar dari critical value baik pada lower bound test $\mathrm{I}(0)$ dan upper bound test $\mathrm{I}(1)$ dengan taraf signifikan $10 \%, 5 \%$ dan $1 \%$. Sehingga dapat disimpulkan bahwa terdapat hubungan jangka panjang antara variabel atau terdapat kointegrasi. 


\section{Estimasi Koefisien Jangka Panjang}

\begin{tabular}{|c|c|c|c|c|}
\hline Variable & Coefficient & Std. Error & t-Statistic & Prob. \\
\hline NPF & 4.833749 & 0.555522 & 8.701274 & 0.0000 \\
\hline FDR & -0.608870 & 0.101905 & -5.974869 & 0.0000 \\
\hline CAR & -1.149589 & 0.358880 & -3.203273 & 0.0020 \\
\hline INFLASI & 0.521054 & 0.303950 & 1.714275 & 0.0904 \\
\hline C & 137.7778 & 13.88366 & 9.923737 & 0.0000 \\
\hline R-squared & 0.839338 & \multicolumn{2}{|c|}{ Mean dependent var } & 85.41298 \\
\hline Adjusted R-squared & 0.831203 & \multicolumn{2}{|c|}{ S.D. dependent var } & 9.136155 \\
\hline S.E. of regression & 3.753577 & \multicolumn{2}{|c|}{ Akaike info criterion } & 5.540974 \\
\hline Sum squared resid & 1113.058 & \multicolumn{2}{|c|}{ Schwarz criterion } & 5.685666 \\
\hline Log likelihood & -227.7209 & \multicolumn{2}{|c|}{ Hannan-Quinn criter. } & 5.599139 \\
\hline F-statistic & 103.1790 & \multicolumn{2}{|c|}{ Durbin-Watson stat } & 1.095817 \\
\hline Prob(F-statistic) & 0.000000 & & & \\
\hline
\end{tabular}

Berdasarkan tabel di atas, persamaan jangka panjang hasil ARDL secara matematis adalah sebagai berikut :

\section{InBOPO = 4.833749*NPF + (-0.608870)*FDR + (-1.149589)*CAR + 0.521054*Inflasi}

Variabel NPF berpengaruh positif dan signifikan terhadap BOPO yang dibuktikan dengan nilai koefisien sebesar 4,833749 dan prob. t sebesar 0,0000 yang lebih kecil dari 0,05. Dimana terdapat hubungan jangka panjang antar NPF dengan BOPO. Nilai koefisien NPF membuktikan bahwa kenaikan pada NPF sebesar 1\% dalam jangka panjang akan meningkatkan BOPO sebesar 4,833749\%. Variabel FDR berpengaruh negatif dan signifikan yang ditunjukkan dengan nilai koefisien -0,608870 dan prob. t sebesar 0,0000 yang lebih kecil dari 0,05. Artinya terdapat hubungan jangka panjang antar FDR dengan BOPO. Nilai koefisien FDR menunjukkan bahwa kenaikan FDR sebesar 1\% dalam jangka panjang akan menurunkan BOPO sebesar 0,608870\%. Variabel CAR berpengaruh negatif dan signifikan yang dibuktikan dengan nilai koefisien -1,149589 dan prob. $t$ sebesar 0,0020 yang lebih kecil dari 0,05. Hal ini menandakan bahwa terdapat hubungan jangka panjang antar CAR dengan BOPO. Nilai koefisien CAR menunjukkan bahwa kenaikan CAR sebesar $1 \%$ dalam jangka panjang akan menurunkan BOPO sebesar $-1,149589 \%$ dan berlaku sebaliknya, yaitu ketika rasio CAR turun, maka BOPO akan naik. Variabel Inflasi berpengaruh positif dan tidak signifikan yang ditunjukkan dengan nilai koefisien sebesar 0,521054 dan prob. t sebesar 0.0904 yang lebih besar dari 0,05. Artinya terdapat hubungan jangka panjang antar Inflasi dengan BOPO. Nilai koefisien Inflasi menunjukkan bahwa kenaikan Inflasi sebesar 1\% dalam jangka panjang akan meningkatkan BOPO sebesar 0,521054\%. Nilai R-Squared dalam koefisien jangka panjang pada penelitian ini sebesar $0.839338 \%$ yang membuktikan bahwa 
persamaan ini mampu menjelaskan sebesar $83 \%$ atas variabel dependen berdasarkan model yang digunakan dan sisanya merupakan variabel lain yang tidak masuk ke dalam model.

\section{Uji Diagnostik pada Model Persamaan Jangka Panjang}

\section{Uji Normalitas}
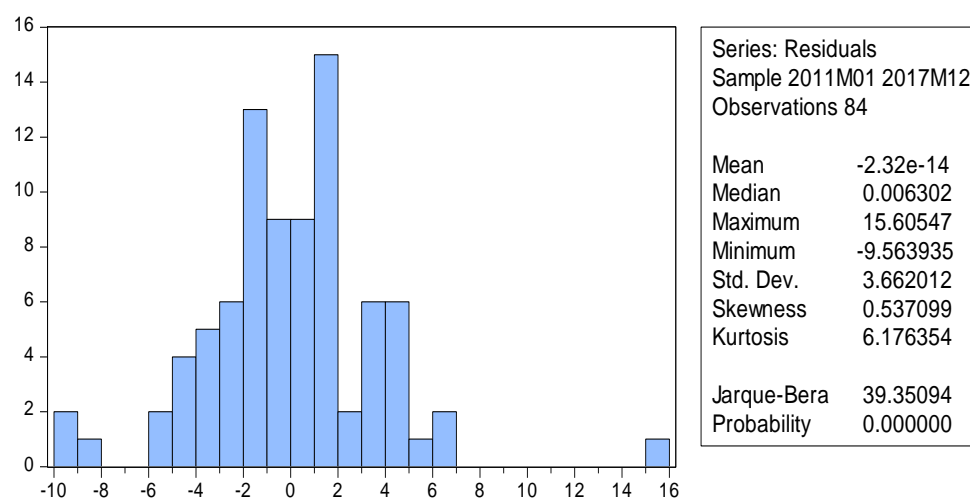

Observations 84

Mean $\quad-2.32 e-14$

Median $\quad 0.006302$

Maximum $\quad 15.60547$

Minimum $\quad-9.563935$

Std. Dev. $\quad 3.662012$

Skewness $\quad 0.537099$

Kurtosis $\quad 6.176354$

Jarque-Bera $\quad 39.35094$

Probability $\quad 0.000000$

Berdasarkan pada gambar tersebut menunjukkan bahwa nilai probability jarque-bera sebesar 0,000000 lebih kecil dari 0,05 sehingga hasil uji normalitas pada estimasi koefisien jangka panjang dalam penelitian ini tidak berdistribusi normal. Namun berdasarkan Central Limit Theory (Dielman, 1961 dalam Ghozali, 2009) yang menyatakan bahwa untuk sampel yang besar terutama lebih dari 30 ( $n \geq 30$ ), distribusi sampel dianggap normal. Dikarenakan sampel dalam penelitian ini lebih dari 30 ( $n \geq 30$ ) sampel yaitu memakai 84 sampel maka uji normalitas dalam estimasi jangka panjang ini dinyatakan terdistribusi dengan normal.

\section{Uji Autokorelasi}

Breusch-Godfrey Serial Correlation LM Test:

\begin{tabular}{llll}
\hline & & & \\
F-statistic & 10.73671 & Prob. F(2,77) & 0.0001 \\
Obs*R-squared & 18.31730 & Prob. Chi-Square(2) & 0.0001 \\
& & & \\
\hline
\end{tabular}

Pada tabel di atas diketahui bahwa nilai probability chi square sebesar 0.0001 dimana lebih kecil dari nilai signifikan 0,05 sehingga dapat di simpulkan persamaan regresi dalam estimasi koefisien jangka panjang pada penelitian ini terjadi autokorelasi.

\section{Uji Heteroskedastisitas}

Heteroskedasticity Test: Breusch-Pagan-Godfrey

\begin{tabular}{llll}
\hline & & & \\
F-statistic & 1.436151 & Prob. F(4,79) & 0.2298 \\
Obs*R-squared & 5.694130 & Prob. Chi-Square(4) & 0.2232 \\
Scaled explained SS & 13.03518 & Prob. Chi-Square(4) & 0.0111 \\
\hline
\end{tabular}


Dapat diketahui bahwa nilai probability chi square sebesar 0.2232 lebih besar dari nilai tingkat signifikan 0,05 atau 5\%. Dapat di simpulkan persamaan regresi jangka panjang dalam penelitian ini tidak terjadi heteroskedastisitas.

\section{Uji Stabilitas pada Model Persamaan Autoregressive Distributed Lag (ARDL)}

\section{Uji CUSUM}

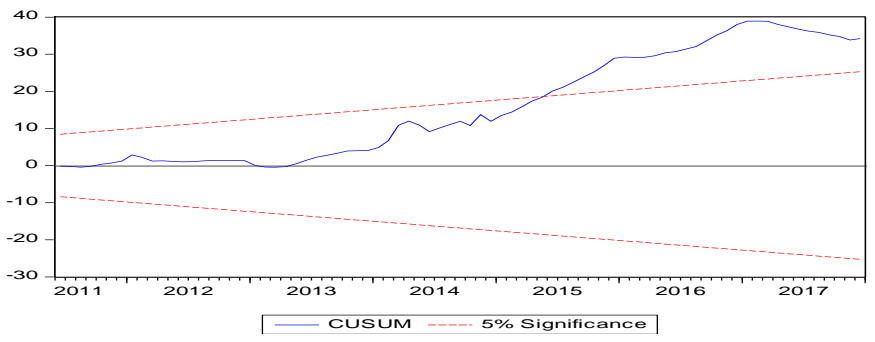

Berdasarkan hasil yang diperoleh dari uji CUSUM dengan taraf signifikansi $5 \%$ pada estimasi koefisien jangka panjang dalam penelitian ini menunjukkan bahwa data berdistribusi cukup stabil.

\section{Uji CUSUMQ}

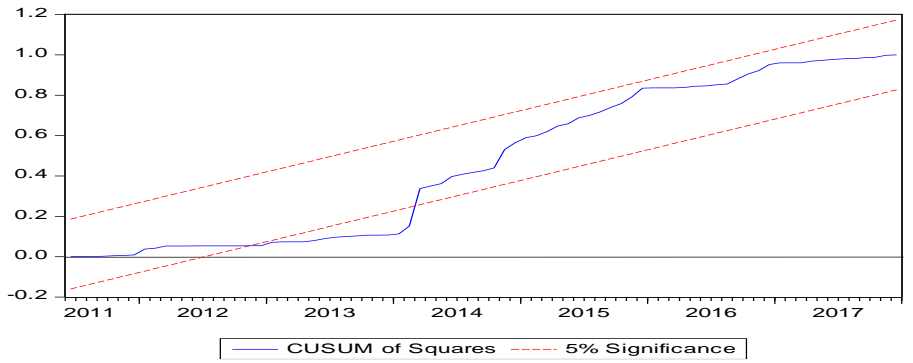

Sama halnya dengan hasil uji CUSUM yang cukup stabil, pada uji CUSUMQ dalam koefesien jangka panjang pada penelitian ini juga memiliki hasil yang cukup stabil dengan taraf signifikansi $5 \%$.

\section{Estimasi Koefisien Jangka Pendek}

\begin{tabular}{crrrr}
\hline & & & & \\
Variable & $\mathrm{t}$ & Std. Error & t-Statistic & Prob. \\
& & & & \\
\hline & & & & \\
$\mathrm{D}(\mathrm{BOPO}(-1))$ & -0.117790 & 0.140858 & -0.836232 & 0.4063 \\
$\mathrm{D}(\mathrm{BOPO}(-2))$ & 0.175361 & 0.123830 & 1.416145 & 0.1618 \\
$\mathrm{D}(\mathrm{NPF})$ & 2.568761 & 1.345171 & 1.909617 & 0.0609 \\
$\mathrm{D}(\mathrm{NPF}(-1))$ & -1.977621 & 1.504926 & -1.314098 & 0.1937 \\
$\mathrm{D}(\mathrm{NPF}(-2))$ & -0.394189 & 1.384552 & -0.284705 & 0.7768 \\
$\mathrm{D}(\mathrm{NPF}(-3))$ & -1.142728 & 1.333610 & -0.856869 & 0.3949 \\
$\mathrm{D}(\mathrm{NPF}(-4))$ & 0.619776 & 1.335929 & 0.463928 & 0.6444 \\
$\mathrm{D}(\mathrm{FDR})$ & -0.329123 & 0.189606 & -1.735823 & 0.0876 \\
$\mathrm{D}(\mathrm{CAR})$ & 0.266375 & 0.509285 & 0.523038 & 0.6028 \\
$\mathrm{D}(\mathrm{CAR}(-1))$ & 1.275335 & 0.529640 & 2.407929 & 0.0191 \\
$\mathrm{D}(\mathrm{CAR}(-2))$ & 0.715574 & 0.562476 & 1.272186 & 0.2081 \\
$\mathrm{D}(\mathrm{CAR}(-3))$ & 0.113518 & 0.479829 & 0.236580 & 0.8138
\end{tabular}


Jurnal el-Amwal, Vol. 4, No. 1, May 2021

\begin{tabular}{crlrl} 
D(CAR(-4)) & 0.196002 & 0.434999 & 0.450581 & 0.6539 \\
D(INFLASI) & -0.407318 & 0.633737 & -0.642725 & 0.5228 \\
D(INFLASI(-1)) & -1.395828 & 0.654489 & -2.132700 & 0.0370 \\
D(INFLASI(-2)) & 1.497973 & 0.623054 & 2.404243 & 0.0193 \\
C & 0.818193 & 0.407195 & 2.009341 & 0.0489 \\
ECT(-1) & -0.553967 & 0.149872 & -3.696262 & 0.0005 \\
& & & \\
\hline & & & \\
R-squared & 0.549683 & Mean dependent var & 0.200759 \\
Adjusted R-squared & 0.424185 & S.D. dependent var & 4.118379 \\
S.E. of regression & 3.125129 & Akaike info criterion & 5.313950 \\
Sum squared resid & 595.7523 & Schwarz criterion & 5.853825 \\
Log likelihood & -191.9010 & Hannan-Quinn criter. & 5.530240 \\
F-statistic & 4.380006 & Durbin-Watson stat & 2.080313 \\
Prob(F-statistic) & 0.000009 & & \\
& & &
\end{tabular}

Berdasarkan tabel di atas persamaan jangka pendek hasil ARDL secara matematis adalah sebagai berikut :

$\Delta / n$ BOPOt $=-0.117790 * \mathrm{BOPO}(-1)+0.175361 * \mathrm{BOPO}(-2))+2.568761 * \mathrm{NPF}+(-1.977621) * \mathrm{NPF}(-1)$ $+(-0.394189) * N P F(-2))+(-1.142728) * N P F(-3)+0.619776 * N P F(-4)+(-0.329123) * F D R+$ $0.266375 *$ CAR $+1.275335 *$ CAR(-1) + 0.715574*CAR(-2) + 0.113518*CAR(-3) + 0.196002*CAR($4)+(-0.407318) *$ Inflasi + (-1.395828)*Inflasi(-1) + 1.497973*Inflasi(-2) + -0.553967*ECT(-1)

Variabel NPF berpengaruh positif dan signifikan terhadap BOPO, hal tersebut dapat dilihat dari nilai koefesien sebesar 2.568761 dengan nilai prob. t sebesar 0.0609. Artinya terdapat hubungan jangka pendek antar NPF dengan BOPO. Hal ini menunjukkan bahwa kenaikan NPF sebesar $1 \%$ dalam jangka pendek akan meningkatkan BOPO sebesar $2.568761 \%$. Variabel FDR berpengaruh negatif dan signifikan terhadap BOPO yang dibuktikan dengan nilai koefisien sebesar -0.329123 dan prob. t sebesar 0.0876. Artinya terdapat hubungan jangka pendek antar FDR dengan BOPO. Hal ini menunjukkan bahwa kenaikan FDR sebesar $1 \%$ dalam jangka pendek akan menurunkan BOPO sebesar $0.329123 \%$. Variabel CAR berpengaruh positif dan signifikan pada bulan pertama (CAR(-1)) dengan nilai koefisien sebesar 1.275335 dan prob. t sebesar 0.0191 yang lebih kecil dari 0,05. Artinya terdapat hubungan jangka pendek antar (CAR(-1)) dengan BOPO. Nilai koefisien CAR(-1) menunjukkan bahwa kenaikan CAR pada satu bulan sebelumnya sebesar $1 \%$ dalam jangka pendek akan meningkatkan BOPO pada bulan sekarang sebesar $1.275335 \%$. Variabel Inflasi pada bulan pertama (Inflasi(-1)) dan bulan kedua (Inflasi(-2)) berpengaruh signifikan. Inflasi(-1) berdampak negatif dan Inflasi(-2) berdampak positif terhadap BOPO yang ditunjukkan dengan nilai prob. $t$ masing-masing variabel yaitu sebesar 0,0370 dan 0,0193 yang menunujukkan terdapat hubungan jangka pendek antar Inflasi(-1) dan Inflasi(-2) dengan BOPO. Hal ini mengartikan bahwa peningkatan inflasi sebesar $1 \%$ pada satu bulan sebelumnya akan menurunkan BOPO pada bulan sekarang sebesar $1.395828 \%$ dan peningkatan inflasi sebesar $1 \%$ pada dua bulan sebelumnya akan meningkatkan BOPO pada bulan sekarang sebesar 1,497973\%. Koefisien ECT (Error Correction Term) tercatat sebesar -0.553967 dimana yang artinya tanda 
negatif memberikan penjelasan bahwa variabel NPF, FDR, CAR dan Inflasi berada di atas nilai keseimbangannya sehingga seluruh variabel independen akan meningkat pada periode berikutnya untuk mengoreksi kesalahan keseimbangan jangka pendek ke jangka panjang. Nilai probabilitas yang di dapat koefisien ECT adalah sebesar 0.0005 , hal ini berarti ECT sudah signifikan pada tingkat $\alpha$ (5\%). Oleh karena itu, model dari pengujian ARDL ini dapat dikatakan valid. Nilai R-Squared dalam koefisien jangka pendek pada penelitian ini sebesar $0.549683 \%$ dimana menjelaskan bahwa persamaan ini mampu menjabarkan sebesar $54 \%$ atas variabel dependen berdasarkan model yang digunakan dan sisanya merupakan variabel lain yang tidak masuk dalam model.

\section{Uji Diagnostik pada Model Persamaan Jangka Panjang}

\section{Uji Normalitas}

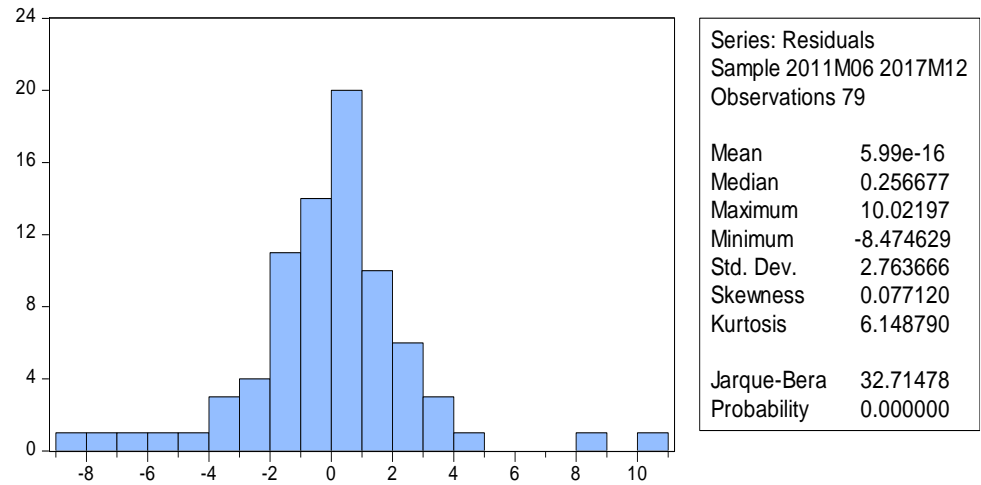

Berdasarkan pada gambar di atas dapat di ketahui hasil dari probability jarque-bera yaitu sebesar 0,000000 yang lebih kecil dari 0,05 maka hasil uji normalitas pada estimasi koefisien jangka pendek dalam penelitian ini tidak berdistribusi normal. Berdasarkan Central Limit Theory (Dielman, 1961 dalam Ghozali, 2009) yang menyatakan bahwa untuk sampel yang besar terutama lebih dari 30 ( $n \geq 30$ ), distribusi sampel di anggap normal. Dikarenakan sampel dalam penelitian ini lebih dari 30 ( $n \geq 30$ ) sampel yaitu memakai 84 sampel maka uji normalitas dalam estimasi jangka pendek ini dinyatakan terdistribusi dengan normal.

\section{○ Uji Autokorelasi}

Breusch-Godfrey Serial Correlation LM Test:

\begin{tabular}{llll}
\hline & & & \\
F-statistic & 0.911651 & Prob. F(2,59) & 0.4074 \\
Obs*R-squared & 2.368186 & Prob. Chi-Square(2) & 0.3060 \\
\hline
\end{tabular}

Berdasarkan tabel di atas menunjukkan bahwa nilai probability chi square sebesar 0.3060 lebih kecil dari nilai signifikan 0,05 sehingga dapat di simpulkan persamaan regresi dalam estimasi koefisien jangka pendek pada penelitian ini tidak terjadi autokorelasi. 


\section{Uji Heteroskedastisitas}

Heteroskedasticity Test: Breusch-Pagan-Godfrey

\begin{tabular}{llll}
\hline & & & \\
F-statistic & 1.296623 & Prob. F(17,61) & 0.2255 \\
Obs*R-squared & 20.96954 & Prob. Chi-Square(17) & 0.2277 \\
Scaled explained SS & 32.18619 & Prob. Chi-Square(17) & 0.0143 \\
\hline
\end{tabular}

Hasil uji heteroskedastisitas di atas menunjukkan nilai probability chi square sebesar 0.2277 dimana lebih besar dari nilai tingkat signifikan 0,05 atau 5\% sehingga dapat di simpulkan persamaan regresi pada jangka pendek dalam penelitian ini tidak terjadi heteroskedastisitas.

\section{Uji Stabilitas pada Model Persamaan Autoregressive Distributed Lag (ARDL)}

\section{Uji CUSUM}

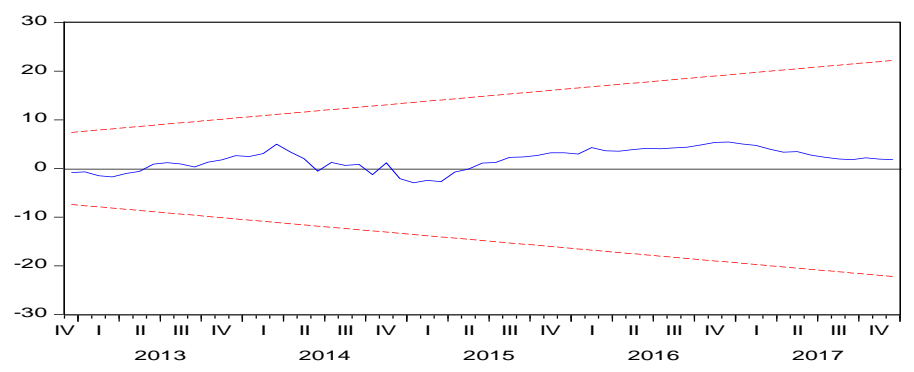

Berdasarkan hasil uji CUSUM pada koefisien jangka pendek dalam penelitian ini menunjukkan bahwa garis berwarna biru tetap berada diantara significance line $5 \%$ yang berwarna merah. Sehingga membuktikan model ARDL pada koefisien jangka pendek stabil.

\section{Uji CUSUMQ}

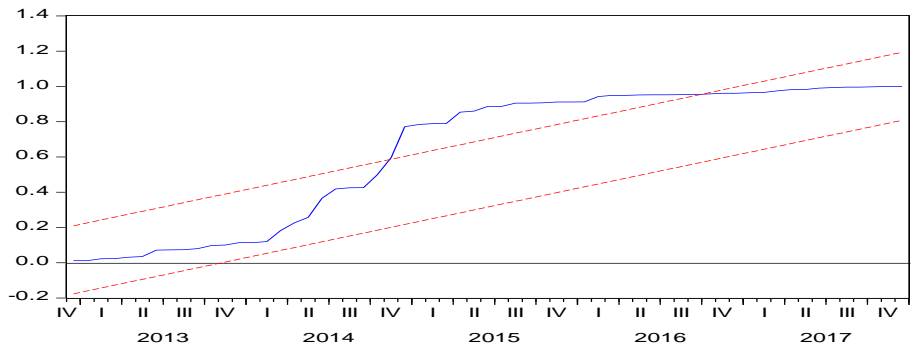

CUSUM of Squares $-\ldots .-5 \%$ Significance

Hasil yang di dapat pada uji CUSUMQ seperti yang di tampilkan pada gambar tersebut di atas menyatakan bahwa persamaan regresi pada koefesien jangka pendek dalam penelitian ini cukup stabil.

\section{KESIMPULAN}

Dari hasil penelitian diatas menunjukkan bahwa pada jangka panjang dan jangka pendek NPF berpengaruh positif dan signifikan terhadap BOPO. Pada jangka panjang dan jangka pendek FDR berpengaruh negatif dan signifikan terhadap BOPO. Varibel inflasi dalam jangka panjang dan jangka pendek berpengaruh positif, namun dalam jangka pendek inflasi yang berpengaruh positif 
terdapat pada inflasi(-2) atau bulan kedua. Selanjutnya pada jangka pendek inflasi(-1) atau inflasi bulan pertama berpengaruh negatif signifikan terhadap BOPO. Hal ini menunjukkan bahwa pengaruh variabel NPF, FDR, dan Inflasi terhadap BOPO menunjukkan pengaruh yang konsisten, dimana hal ini mengartikan bahwa adanya koreksi dari jangka panjang ke jangka pendek. Sedangkan pengaruh variabel CAR terhadap BOPO pada jangka panjang menunjukan hubungan negatif dan signifikan sedangkan pada jangka pendek CAR memiliki pengaruh positif signifikan terhadap BOPO. Hal ini menunjukkan bahwa variabel CAR memiliki pengaruh yang tidak konsisten.

\section{REFERENSI}

Abdul Karim, M., Hassan, M. K., Hassan, T., \& Mohamad, S. (2014). Capital adequacy and lending and deposit behaviors of conventional and Islamic banks. Pacific Basin Finance Journal, 28(1), 58-75. https://doi.org/10.1016/j.pacfin.2013.11.002

Adhitya Wardhono, Utfi Aini, Y. I. (2013). Netralitas Uang di Dalam Siklus Bisnis di Indonesia: Pendekatan Model Dinamis. 2(1), 77-97.

Agus, W. (2013). Ekonometrika Pengantar Dan Aplikasinya. Ekonosia. Jakarta.

Aprianti, N. R. (2019). Analisis Pengaruh Rasio Keungan Perbankan Terhadap Profitabilitas Pada Bank Umum Konvensional di Indonesia. Universitas Islam Indonesia.

Arif, M. N. R. Al. (2010). Teori Makroekonomi Islam: Konsep, Teori, dan Analisis (cet. ke-1). Bandung: Alfabeta.

Ascarya. (2008). Akad dan Produk Bank Syariah. jakarta : PT Raja Grafindo Persada.

Auliani, M. M. (2016). Analisis Pengaruh Faktor Internal dan Faktor Eksternal Terhadap Tingkat Pembiayaan Bermasalah pada Bank Umum Syariah Di Indonesia Periode Tahun 2010-2014. Diponegoro Journal of Management, 5(3), 1-14. http://ejournals1.undip.ac.id/index.php/dbr

Baldwin, K., Alhalboni, M., \& Helmi, M. H. (2019). A structural model of "alpha" for the capital adequacy ratios of Islamic banks. Journal of International Financial Markets, Institutions and Money, 60(2), 267-283. https://doi.org/10.1016/j.intfin.2018.12.015

Bambang Rianto Rustam. (2013). Manajemen Risiko Perbankan Syariah di Indonesia. Jakarta: Salemba Empat.

Darmawan, D. (2013). Metode Penelitian Kuantitatif. Bandung: PT. Remaja Rosdakarya.

Devitra, J. (2011). Kinerja keuangan dan efisiensi terhadap. Jurnal Keuangan Dan Perbankan, 15(1), 38-53.

Fahmi, I. (2014). Pengantar Perbankan Teori dan Aplikasi. Bandung: Alfabeta.

Gujarati, D. (2004). Dasar-dasar ekonometrika. Solo: salemba empat. 
Haifa, H., \& Wibowo, D. (2015). Pengaruh Faktor Internal Bank Dan Makro Ekonomi Terhadap Non Performing Financing Perbankan Syariah Di Indonesia: Periode 2010:01 - 2014:04. Nisbah: Jurnal Perbankan Syariah, 1(2), 74. https://doi.org/10.30997/jn.v1i2.253

Hasibuan, M. S. P. (2011). Dasar-Dasar Perbankan. Jakarta : PT. Bumi Aksara.

Hidayat, S. P., \& Prasetyo, A. (2016). Pengaruh Non Performing Financing, Financing to Deposit Ratio dan Inflasi Terhadap Efesiensi Menggunakan Rasio BOPO Pada Bank Syariah di Indonesia Periode 2010-2015. Jurnal Ekonomi Syariah Dan Terapan, 4(3), 187-202.

Ismail. (2011). Perbankan Syariah (ed. 1). Prenadamedia Group.

Jamilah. (2016). Faktor-Faktor yang Mempengaruhi Pembiayaan Mudharabah pada Bank Umum Syariah di Indonesia. Jurna IImu Dan Riset Akuntansi, 5(4), 20.

Larasati, D. M., \& Amri. (2017). Pengaruh Tingkat Suku Bunga Sertifikat Bank Indonesia dan Nilai Tukar terhadap Inflasi di Indonesia. Jurnal IImiah Mahasiswa, 2(4), 535-543.

Laurensius Marshall Sautlan Sitanggang dan Yudho Winarto. (2018, October). Makin efisien, BOPO bank syariah terendah selama 4 tahun terakhir. Www.Kontan.Co.Id. https://keuangan.kontan.co.id/news/makin-efisien-bopo-bank-syariah-terendah-selama4-tahun-terakhir

Laurentia, P., \& Lindrawati, L. (2010). Pengaruh Capital Adequacy Ratio dan Financing To Deposit Ratio terhadap Laba Bank Umum Syariah. Jurnal Akuntansi Kontemporer, 2(1), 245126.

Miah, M. D., Kabir, M. N., \& Safiullah, M. (2020). Switching costs in Islamic banking: The impact on market power and financial stability. Journal of Behavioral and Experimental Finance, 28(2), 1-18. https://doi.org/10.1016/j.jbef.2020.100409

Muhammad Syakhrun, Asbi Amin, A. (2019). Pengaruh CAR, BOPO, NPF dan FDR Terhadap Profitabilitas Pada Bank Umum Syariah di Indonesia. Pengaruh CAR, BOPO, NPF Dan FDR Terhadap Profitabilitas Pada Bank Umum Syariah Di Indonesia, 2(April), 1-10.

Munardi, Ahmad Fauzul Hakim Hasibuan, Ichsan. (2020). Analisis Dampak Tingkat Literasi Keuangan Syriah, Produk Keuangan Syariah. J-EBIS (Jurnal Ekonomi Dan Bisnis Islam), 5(2), 109-126.

Nuraini dan Taufik Rachman. (2011, September). Perbankan Syariah Tahan Banting Hadapi Krisis Global I Republika Online. Www.Republika.Co.Id. https://republika.co.id/berita/ekonomi/keuangan/11/09/26/Is3sl0-perbankan-syariahtahan-banting-hadapi-krisis-global

Peraturan Bank Indonesia No. 8/21/PBI/2006. (n.d.). Tentang Penilaian Kualitas Aktiva Bank Umum Yang Melaksanakan Kegiatan Usaha Berdasarkan Prinsip Syariah. Diunduh: 19 september 2020.

Putri, N. K. A. P., Wiagustini, L. P., \& Abundanti, N. N. (2018). Pengaruh Npl, Car Dan Bopo Terhadap Profitabilitas Pada Bpr Di Kota Denpasar. E-Jurnal Manajemen Universitas Udayana, 7(11), 6212. https://doi.org/10.24843/ejmunud.2018.v07.i11.p15 
Ridwan, M. (2016). Pengaruh Intellectual Capital, Capital Adequacy Ratio (CAR) dan Financing to Deposit Ratio (FDR) Terhadap Profitabilitas Bank Umum Syariah di Indonesia. Universitas Muhammadiyah Semarang.

Rivai, V. (2007). Bank and Financial Institution Management (ed. 1). Jakarta: PT Raja Grafindo Persada.

Robby Milana. (2015, June). Perbankan Syariah Kebal di Tengah Krisis - Kompasiana.com. Www.Kompasiana.Com.

https://www.kompasiana.com/resonansi/550120ffa33311be0b51141c/perbankansyariah-kebal-di-tengah-krisis

Sahyouni, A., \& Wang, M. (2019). Liquidity creation and bank performance: evidence from MENA. ISRA International Journal of Islamic Finance, 11(1), 27-45. https://doi.org/10.1108/IJIF-012018-0009

Septiputri, V. R. (2013). Dampak Corporate Governance Terhadap Profitabilitas Perbankan Syariah Indonesia Tahun 2007-2011. In Diponegoro Journal of Accounting. Universitas Diponegoro Semarang.

Slamet Riyadi, A. Y. (2014). Pengaruh Pembiayaan Bagi Hasil, Pembiayaan Jual Beli, Financing To Deposit Ratio (Fdr) Dan Non Performing Financing (Npf) Terhadap Profitabilitas Bank Umum Syariah Di Indonesia. Accounting Analysis Journal, 3(4), 466-474. https://doi.org/10.15294/aaj.v3i4.4208

Sudarsono, H. (2018). Analisis Pengaruh Variabel Mikro dan Makro Terhadap NPF Perbankan Syariah di Indonesia. Equilibrium: Jurnal Ekonomi Syariah, 6(1), 1-18. https://doi.org/10.21043/equilibrium.v6i1.3040

Susilowati, Y., Nur Aini Tjahjaning Poerwati, \& Rahayuningsih, R. (2019). Analisis kecukupan modal, efisiensi dan likuiditas terhadap profitabilitas. Prosiding SENDI_U, 3(1), 1-8.

Swandayani, D. M., \& Kusumaningtias, R. (2012). Pengaruh Inflasi, Suku Bunga, Nilai Tukar Valas Dan Jumlah Uang Beredar Terhadap Profitabilitas Pada Perbankan Syariah Di Indonesia Periode 2005-2009. AKRUAL: Jurnal Akuntansi, 3(2), 147-166. https://doi.org/10.26740/jaj.v3n2.p147-166

Veithzal Rivai, D. (2010). Islamic Banking: Sebuah Teori, Konsep dan Aplikasi. Jakarta: Bumi Aksara.

Wasiaturrahma, Ajija, S. R., Sukmana, R., Sari, T. N., \& Hudaifah, A. (2020). Breadth and depth outreach of Islamic cooperatives: do size, non-performing finance, and grant matter? Heliyon, 6(7), 1-9. https://doi.org/10.1016/j.heliyon.2020.e04472

Widarjono, A. (2018). Ekonometrika Pengantar dan Aplikasinya Disertai Panduan Eviews. UPP STIM YKPN: Yogyakarta.

Yayu Agustini Rahayu. (2017, October). Gelar Pertemuan Tahunan, Bank Indonesia bahas momentum pemulihan ekonomi Indonesia I merdeka.com. 
Jurnal el-Amwal, Vol. 4, No. 1, May 2021

Www.Merdeka.Com.https://www.merdeka.com/uang/gelar-pertemuan-tahunan-bankindonesia-bahas-momentum-pemulihan-ekonomi-indonesia.html 